\title{
Trace elements in major marketed marine bivalves from six northern coastal cities of China: Concentrations and risk assessment for human health
}

\author{
Peimiao Li ${ }^{\mathrm{a}, \mathrm{b}}$, Xuelu Gao ${ }^{\mathrm{a}, *}$ \\ ${ }^{a}$ Key Laboratory of Coastal Environmental Processes and Ecological Remediation, Yantai Institute of Coastal Zone Research, \\ Chinese Academy of Sciences, Yantai, Shandong 264003, China \\ ${ }^{\mathrm{b}}$ University of the Chinese Academy of Sciences, Beijing 100049, China
}

\section{A R T I C L E I N F O}

\section{Article history:}

Received 17 February 2014

Received in revised form

22 July 2014

Accepted 23 July 2014

Available online 15 August 2014

Keywords:

Trace elements

Bivalves

Contamination

Bioaccumulation

Health risk assessment

\begin{abstract}
A B S T R A C T
One hundred and fifty nine samples of nine edible bivalve species (Argopecten irradians, Chlamys farreri, Crassostrea virginica, Lasaea nipponica, Meretrix meretrix, Mytilus edulis, Ruditapes philippinarum, Scapharca subcrenata and Sinonovacula constricta) were randomly collected from eight local seafood markets in six big cities (Dalian, Qingdao, Rizhao, Weifang, Weihai and Yantai) in the northern coastal areas of China for the investigation of trace element contamination. $\mathrm{As}, \mathrm{Cd}, \mathrm{Cr}, \mathrm{Cu}, \mathrm{Hg}, \mathrm{Pb}$ and $\mathrm{Zn}$ were quantified. The risk of these trace elements to humans through bivalve consumption was then assessed. Results indicated that the concentrations of most of the studied trace element varied significantly with species: the average concentration of $\mathrm{Cu}$ in $\mathrm{C}$. virginica was an order of magnitude higher than that in the remaining species; the average concentration of $\mathrm{Zn}$ was also highest in $C$. virginica; the average concentration of $\mathrm{As}, \mathrm{Cd}$ and $\mathrm{Pb}$ was highest in $R$. philippinarum, $C$. farreri and $A$. irradians, respectively. Spatial differences in the concentrations of elements were generally less than those of interspecies, yet some elements such as $\mathrm{Cr}$ and $\mathrm{Hg}$ in the samples from different cities showed a significant difference in concentrations for some bivalve species. Trace element concentrations in edible tissues followed the order of $\mathrm{Zn}>\mathrm{Cu}>\mathrm{As}>\mathrm{Cd}>\mathrm{Cr}>\mathrm{Pb}>\mathrm{Hg}$ generally. Statistical analysis (one-way ANOVA) indicated that different species examined showed different bioaccumulation of trace elements. There were significant correlations between the concentrations of some elements. The calculated hazard quotients indicated in general that there was no obvious health risk from the intake of trace elements through bivalve consumption. But care must be taken considering the increasing amount of seafood consumption.
\end{abstract}

(c) 2014 Elsevier Inc. All rights reserved.

\section{Introduction}

The Earth system is currently operating in a no-analogue state, and human activities are significantly altering the environment on a global scale (Steffen et al., 2004). Massive amounts of inorganic/ organic substances are discharged into the environment each year, transforming into pollutants and usually having negative effects. Trace elements are natural and fundamental components of the geosphere and biosphere. Many trace elements are essential to maintain the metabolism of organisms. However, they can be poisonous if their concentrations exceed certain limits. Once entering the environment, these elements cannot be degraded or destroyed but tend to bioaccumulate and increase in the

\footnotetext{
* Corresponding author. Fax: +86535 2109000.

E-mail address: xlgao@yic.ac.cn (X. Gao).
}

concentrations over time, pass along the food chain and directly/ indirectly influence human health. Many environmental quality guidelines, within which trace elements such as arsenic (As), cadmium $(\mathrm{Cd})$, chromium $(\mathrm{Cr})$, copper $(\mathrm{Cu})$, mercury $(\mathrm{Hg})$, lead $(\mathrm{Pb})$ and zinc $(\mathrm{Zn})$ are usually used as criteria, have been developed to deal with environmental concerns as well as to respond to regulatory programs (e.g. Rawson and Burton, 2002).

Fishery products are a very valuable source of protein and can provide essential micronutrients for human beings. The Food and Agriculture Organization of the United Nations (FAO) reported that fisheries and aquaculture supplied the world with about 128 million tons of food for people in 2010 (FAO (Food and Agricultural Organization of the United Nations), 2012). The share of aquaculture in the world's total fishery yield has been increasing significantly in recent years. China has been the world's leading aquaculture producer for decades and the aquaculture production accounted for 82 percent of the world's marine farmed 
fishery yield in 2010 (FAO (Food and Agricultural Organization of the United Nations), 2012). Marine aquaculture production accounted for 39 percent of the total aquaculture production of China in 2010, about 70 percent of this was comprised of bivalves such as clams, oysters, scallops, mussels and cockles. As the country's first- and fourth-biggest marine aquaculture producers, respectively, Shandong and Liaoning Provinces together contributed 42.4 percent of the marine aquaculture production in China in 2011 according to the report from the BFMAC (Bureau of Fisheries of the Ministry of Agriculture of China) (2012).

The coastal zone is the main area for marine bivalve farming; meanwhile it traps a majority of pollutants in the process of transporting pollutants from land to sea. Most marine bivalves bury themselves in sediment on the seabed, some lie on the sea floor or attach themselves to rocks or other hard surfaces and a few can swim a short distance. Their living habits make them good indicators of environmental quality on a local/regional scale.

The entire coast of the Bohai Sea and the coast of the Yellow Sea in Shandong and Liaoning Provinces are located in the Bohai Sea Economic Rim (Fig. 1), one of the three most densely populated and industrialized zones in China (Gao et al., 2014). Extraordinarily rapid industrial and agricultural development in the northern coastal areas of China has resulted in a significant anthropogenic increase in the ambient levels of pollution and environmental damage in the marine ecosystem (Australian Agency for International Development, 1996; Jacinto, 1997; Xu et al., 2010; Zhang et al., 2010; Gao et al., 2014). Previous reports indicated that the edible marine bivalve species sampled from the Bohai Sea had been contaminated with trace elements to different degrees (Liang et al., 2004; Wang et al., 2005; Du et al., 2009). However, the purpose of these studies was merely monitoring the environmental quality, and there was a lack of risk assessment concerning human health from seafood consumption.

In this study, the edible tissues of nine most marketed marine bivalve species collected from six northern big coastal cities of China, namely Dalian, Qingdao, Rizhao, Weifang, Weihai and Yantai, were analyzed for the determination of $\mathrm{As}, \mathrm{Cd}, \mathrm{Cr}, \mathrm{Cu}, \mathrm{Hg}$, $\mathrm{Pb}$ and $\mathrm{Zn}$. The sampled cities were all located in the Bohai Sea Economic Rim of China. The main objectives of this study were to examine whether the widely consumed bivalve species were contaminated with trace elements, and to test whether there were any spatial or interspecific variations in the concentrations of trace elements. Health risk assessment was then conducted to evaluate whether these bivalves posed any potential risk to human beings as a result of consumption. From a public health perspective, another aim of this study was to provide consumers with better knowledge of contamination problems associated with seafood consumption. We also tried to compare the trace element results with those obtained from other studied coastal areas.

\section{Materials and methods}

\subsection{Sampling}

One hundred and fifty nine samples of nine marine bivalve species of similar sizes were randomly collected from eight large seafood markets in six big cities (Dalian, Qingdao, Rizhao, Weifang, Weihai and Yantai) in the northern coastal areas of China during 6th-27th November 2011 (Fig. 1). To ensure randomness and sufficient representativeness of sampling, 3-4 samples for each species from each city and 10-50 individuals with similar body lengths for each sample were collected. The samples were purchased with their usual conditions in markets and transferred to the laboratory in a cooler box with ice packs. The sampled bivalve species are identified as follows: Argopecten irradians, Chlamys farreri, Crassostrea virginica, Lasaea nipponica, Meretrix meretrix, Mytilus edulis, Ruditapes philippinarum, Scapharca subcrenata and Sinonovacula constricta.

\subsection{Sample analysis}

In the laboratory, the edible tissues of the collected bivalves were then dissected, rinsed with deionized water $(18.2 \mathrm{M} \Omega-\mathrm{cm})$ three times to remove extraneous impurities, and any excess rinsing water was drained off and vaporized. The wet weights of all edible bivalve tissues were first recorded, and the tissues were then freeze dried until constant weights, after which their dry weights were recorded. The percentages of water were calculated and used to convert the trace element concentrations of the samples from a dry weight basis to a wet weight basis. The dried samples were homogenized and ground with a ceramic mortar and stored in small polyethylene zipper bags at $-20{ }^{\circ} \mathrm{C}$ until further analysis.

For each sample, $\sim 0.3 \mathrm{~g}$ of dried and ground soft tissues was weighed and added to a polytetrafluoroethylene (PTFE) digestion container with known weight. Each sample was added with $10 \mathrm{ml}$ of concentrated nitric acid and left to predigest overnight at $80^{\circ} \mathrm{C}$. After cooling, the container was covered and placed in a highpressure stainless steel bomb and then put in an oven. Thereafter the oven temperature was increased to $160{ }^{\circ} \mathrm{C}$ and kept for $8 \mathrm{~h}$ till clarification. After cooling to the room temperature, the solution was diluted with deionized water to the final weight of $50 \mathrm{~g}$ and then transferred into the polyethylene terephthalate (PET) bottle. As, $\mathrm{Cd}, \mathrm{Cr}, \mathrm{Cu}, \mathrm{Pb}$, and $\mathrm{Zn}$ were determined with the PerkinElmer ELAN DRC II

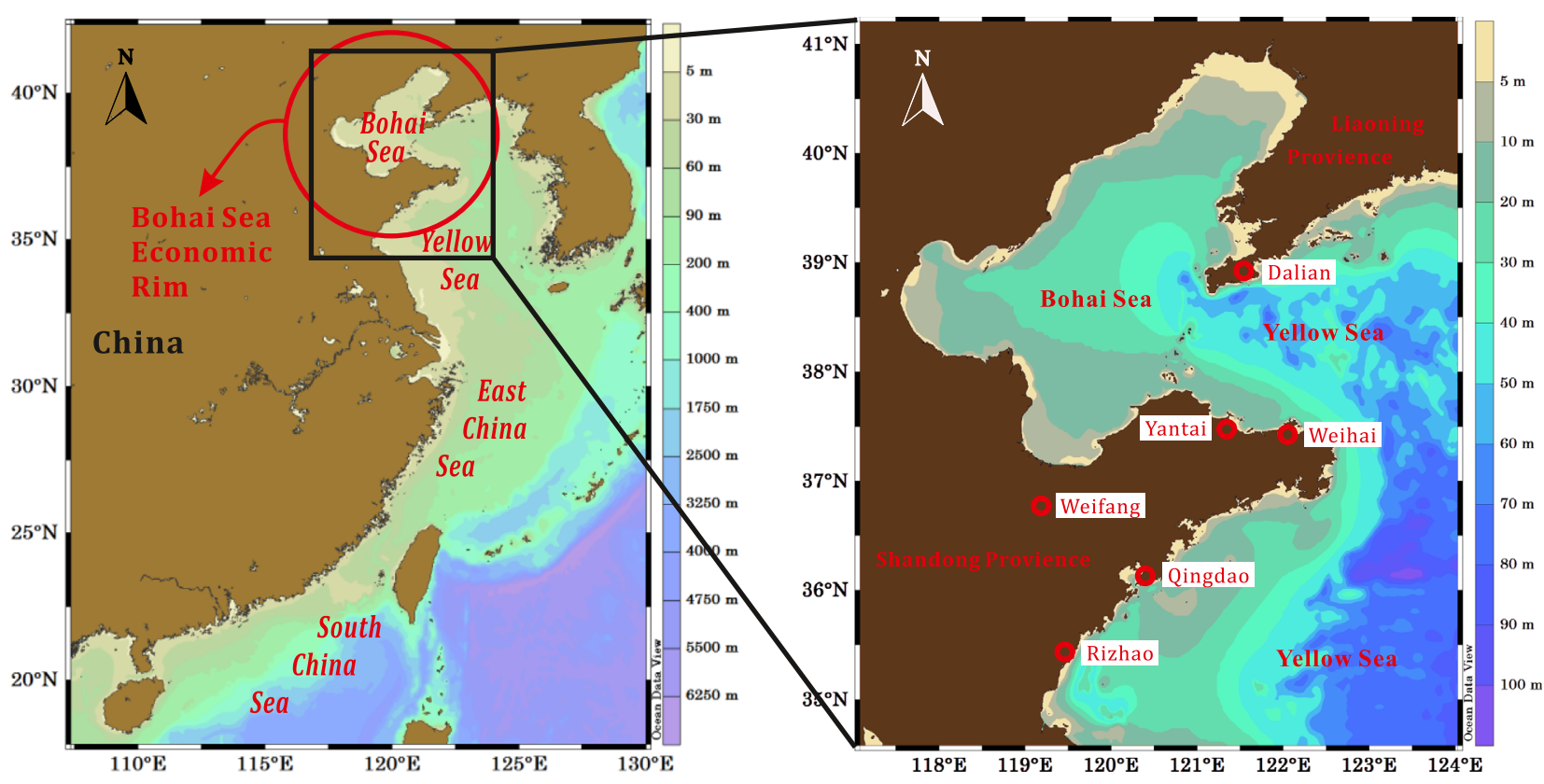

Fig. 1. Sampled cities along the northern coast of China. 
inductively coupled plasma-mass spectrometer. The working parameters are listed below: RF power $1100 \mathrm{~W}$; sampling depth $7 \mathrm{~mm}$; carrier gas flow rate $0.98 \mathrm{l} / \mathrm{min}$; makeup gas flow rate $0.1 \mathrm{l} / \mathrm{min}$; spray chamber temperature $2{ }^{\circ} \mathrm{C}$; sample uptake rate $0.4 \mathrm{ml} / \mathrm{min}$. The openings of the nickel sampling cone and skimmer cone were 1.0 and $0.4 \mathrm{~mm}$, respectively. $\mathrm{Hg}$ was specifically analyzed using a selective hydride generation-atomic fluorescence spectrometer.

All the analyses were repeated three times by external calibration method and all the samples were blank-subtracted. The accuracy of the digestion method was validated by the determination of certified reference materials-mussel (GBW 08571) and Pseudosciaena crocea (GBW 08573), and the results are listed in Table $\mathrm{S} 1$. The recorded values of all elements were in good agreement with the certified values, with the recoveries ranging from 82.7 percent to 112.3 percent, suggesting that the applied method was feasible in the determination of trace metals in biota samples. The method detection limit was defined as three times the standard deviation of the blank samples or as the instrumental detection limit (IDL) if the blanks had no detectable contamination. IDL values were all lower than $0.1 \mathrm{ng} / \mathrm{g}$. The relative standard deviations were within 5 percent for all trace elements. The concentrations of the studied trace elements were expressed as $\mu \mathrm{g} / \mathrm{g}$ wet weight of the edible tissues of the collected bivalves.

All glass vessels were pre-cleaned by soaking in 50 percent $(\mathrm{v} / \mathrm{v})$ nitric acid solution for at least $12 \mathrm{~h}$ and then rinsed with deionized water for several times. The PTFE containers were boiled with 50 percent $(\mathrm{v} / \mathrm{v})$ nitric acid solution and the PET bottles were immersed in 5 percent $(\mathrm{v} / \mathrm{v})$ nitric acid solution for $24 \mathrm{~h}$ followed by rinsing with deionized water.

The nitric acid used was guarantee reagent. The stock calibration standards were adopted from the Chinese CRM/RM Information Center. The standards for calibration curves were prepared by diluting the stock solution with deionized water. The mixture of $5.0 \mathrm{ng} / \mathrm{g}{ }^{115} \mathrm{In}$ in $1 \mathrm{~N}$ nitric acid solution was used as calibration internal standard.

\subsection{Statistical analysis}

Statistical analyses were performed by SPSS version 16.0 for Windows. Oneway analysis of variance (ANOVA) and post-hoc least significant difference tests followed by correlation analysis (bivariate correlations) were used to extract information from the chemical analysis in order to find out the relationships among the trace elements (Capelli et al., 2000; Szefer et al., 2002). In this work, the results of chemical analysis were presented as mean \pm SD. The value of $P<0.05$ was considered to indicate a significant difference in all statistical analysis. Cluster analysis was performed based on the analytical data by unweighted pair-group average method, using Kendall correlation coefficient as a measure of similarity, to obtain a visual representation of spatial and interspecific variations among the trace element concentrations.

\subsection{Human exposure assessment}

The health risk assessment for people from the northern China was conducted using the provisional tolerance weekly intake (PTWI), acceptable daily intake (ADI), and reference dose ( $R f D$ ) established by the United States Environmental Protection Agency (USEPA) and the Joint FAO/World Health Organization (WHO) Expert Committee on Food Additives (JECFA) (USEPA (United States Environmental Protection Agency), 2011; JECFA (Joint FAO/WHO Expert Committee on Food Additives), 2003). The estimated daily intake (EDI) $(\mu \mathrm{g} / \mathrm{kg} /$ day) was calculated using the following equation: $E D I=C_{\text {bivalve }} \times\left(d c_{\text {bivalve }} / b w\right)$, where $C_{\text {bivalve }}=$ average trace element concentration in bivalve $\left(\mu \mathrm{g} / \mathrm{g}\right.$ wet weight), $d c_{\text {bivalve }}=$ daily bivalve consumption (g/day) per capita of Chinese mainland residents in 2011 as reported by the FAO (Food and Agricultural Organization of the United Nations) (2011) and the BFMAC (Bureau of Fisheries of the Ministry of Agriculture of China) (2012), and $b w=$ the average body weight $(\mathrm{kg})$ of the target population. The hazard quotient $(H Q)$ was calculated using the following equation: $H Q=E D I / R f D$. If the $H Q$ was less than one, there would be no obvious risk of excessive intake of trace element from bivalve consumption.

\section{Results and discussion}

\subsection{Levels of trace element concentrations}

The concentrations of trace elements in the edible parts of the nine major marketed bivalves from six northern coastal cities of China are shown in Fig. 2 and summarized in Table 1. The results indicated that $\mathrm{As}, \mathrm{Cr}, \mathrm{Hg}$, and $\mathrm{Pb}$ in all the collected bivalve species had comparable levels while $\mathrm{Cd}, \mathrm{Cu}$, and $\mathrm{Zn}$ exhibited apparent differences in different bivalve species. The concentrations of each trace element in marketed bivalves were described below and compared with earlier studies on bivalves (Table 1 ).
The concentrations of As had a narrow range of variation (0.87$2.94 \mu \mathrm{g} / \mathrm{g}$ ) in different species, consistent with previous observations on bivalves $(0.18-2.97 \mu \mathrm{g} / \mathrm{g}$ ) (Lafabrie et al., 2007; Wang et al., 2007; Whyte et al., 2009). By estimating inorganic As concentration to be 10 percent of the total arsenic concentration according to the USFDA (United States Food and Drug Administration) (1993), the As levels in all the collected bivalve species were all within the restrictive range (inorganic As $1.0 \mu \mathrm{g} / \mathrm{g}$ wet weight) set up by the AQSIQ (General Administration of Quality Supervision, Inspection and Quarantine of the People's Republic of China) (2001).

The Cd levels had a wide range of variation $(0.04-6.44 \mu \mathrm{g} / \mathrm{g})$ and showed big differences among different species, which were consistent with previous observations on bivalves $(0.04-6.5 \mu \mathrm{g} / \mathrm{g}$ ) (Lafabrie et al., 2007; Liu et al., 2007; Ruan, 2008; Whyte et al., 2009). The Cd levels in A. irradians and C. farreri from all the sampled cities, Crassostrea gigas from Weihai and Yantai, and S. subcrenata from Qingdao and Rizhao were all higher than the safety level of $2.0 \mu \mathrm{g} / \mathrm{g}$ wet weight set up by the WHO (1982). L. nipponica, M. meretrix, $R$. philippinarum and $S$. constricta had comparably low Cd concentrations with insignificant differences among the sampled cities. C. farreri from Qingdao had the highest Cd level $(6.44 \mu \mathrm{g} / \mathrm{g})$, which was 160 times higher than the lowest Cd level $(0.04 \mu \mathrm{g} / \mathrm{g})$ of $S$. constricta from Weihai.

The concentrations of $\mathrm{Cr}$ in different bivalve species from different cities ranged from 0.09 to $4.91 \mu \mathrm{g} / \mathrm{g}$, which were comparable with previous observations on bivalves $(0.18-3.65 \mu \mathrm{g} / \mathrm{g}$ ) (Lafabrie et al., 2007; Sivaperumal et al., 2007). M. edulis from Yantai had the highest $\mathrm{Cr}$ concentration, while the lowest $\mathrm{Cr}$ concentration was found in S. subcrenata from Weihai. The $\mathrm{Cr}$ levels in all the collected edible bivalve species were all within the restrictive range $(2.0 \mu \mathrm{g} / \mathrm{g}$ wet weight $)$ set up by the AQSIQ except M. edulis and C. farreri from Yantai (AQSIQ (General Administration of Quality Supervision, Inspection and Quarantine of the People's Republic of China), 2001). No significant difference was found among different species with a few exceptions.

The $\mathrm{Cu}$ levels ranged from 0.68 to $95.27 \mu \mathrm{g} / \mathrm{g}$ and showed a big difference among different species. C. gigas from Yantai showed the highest $\mathrm{Cu}$ level $(95.27 \mu \mathrm{g} / \mathrm{g})$, about 140 times higher than the lowest $\mathrm{Cu}$ level $(0.68 \mu \mathrm{g} / \mathrm{g})$ of $L$. nipponica from Weifang. The $\mathrm{Cu}$ levels in C. gigas $(26.82 \mu \mathrm{g} / \mathrm{g}$ from Dalian, $70.41 \mu \mathrm{g} / \mathrm{g}$ from Qingdao, $75.11 \mu \mathrm{g} / \mathrm{g}$ from Rizhao, $86.66 \mu \mathrm{g} / \mathrm{g}$ from Weifang, $61.10 \mu \mathrm{g} / \mathrm{g}$ from Weihai, and $95.27 \mu \mathrm{g} / \mathrm{g}$ from Yantai) were all the highest among the studied bivalve species from different sampled cities. Other bivalve species had comparable levels. The $\mathrm{Cu}$ concentrations in the collected edible bivalve species except $C$. gigas from Qingdao, Rizhao, Weifang, Weihai and Yantai, were all lower than the safety level of $50 \mu \mathrm{g} / \mathrm{g}$ wet weight set up by the AQSIQ (General Administration of Quality Supervision, Inspection and Quarantine of the People's Republic of China) (2001). The concentrations of $\mathrm{Cu}$ in bivalves have been previously reported at $1.38-10.25 \mu \mathrm{g} / \mathrm{g}$ (Wang et al., 2007) and $1.17-24.1 \mu \mathrm{g} / \mathrm{g}$ (Sivaperumal et al., 2007). Our results were thus 4-9 times higher than those previous measurements. Ruan (2008) reported comparable $\mathrm{Cu}$ levels of $0.88-60.3 \mu \mathrm{g} / \mathrm{g}$ in four bivalve species from Xiamen, China.

Meanwhile, the concentrations of $\mathrm{Hg}$ in different bivalve species were generally low $(0.01-0.15 \mu \mathrm{g} / \mathrm{g})$ among different sampled cities, which had comparable levels with previous observations on bivalves (0.006-0.12 $\mu \mathrm{g} / \mathrm{g}$ ) (Lafabrie et al., 2007; Liu et al., 2007; Wang et al., 2007; Whyte et al., 2009). The Hg levels in the collected edible bivalve species were all within the restrictive level $(0.3 \mu \mathrm{g} / \mathrm{g}$ wet weight) set up by the AQSIQ (General Administration of Quality Supervision, Inspection and Quarantine of the People's Republic of China) (2001). No clear spatial difference was found among all the sampled cities. The highest 


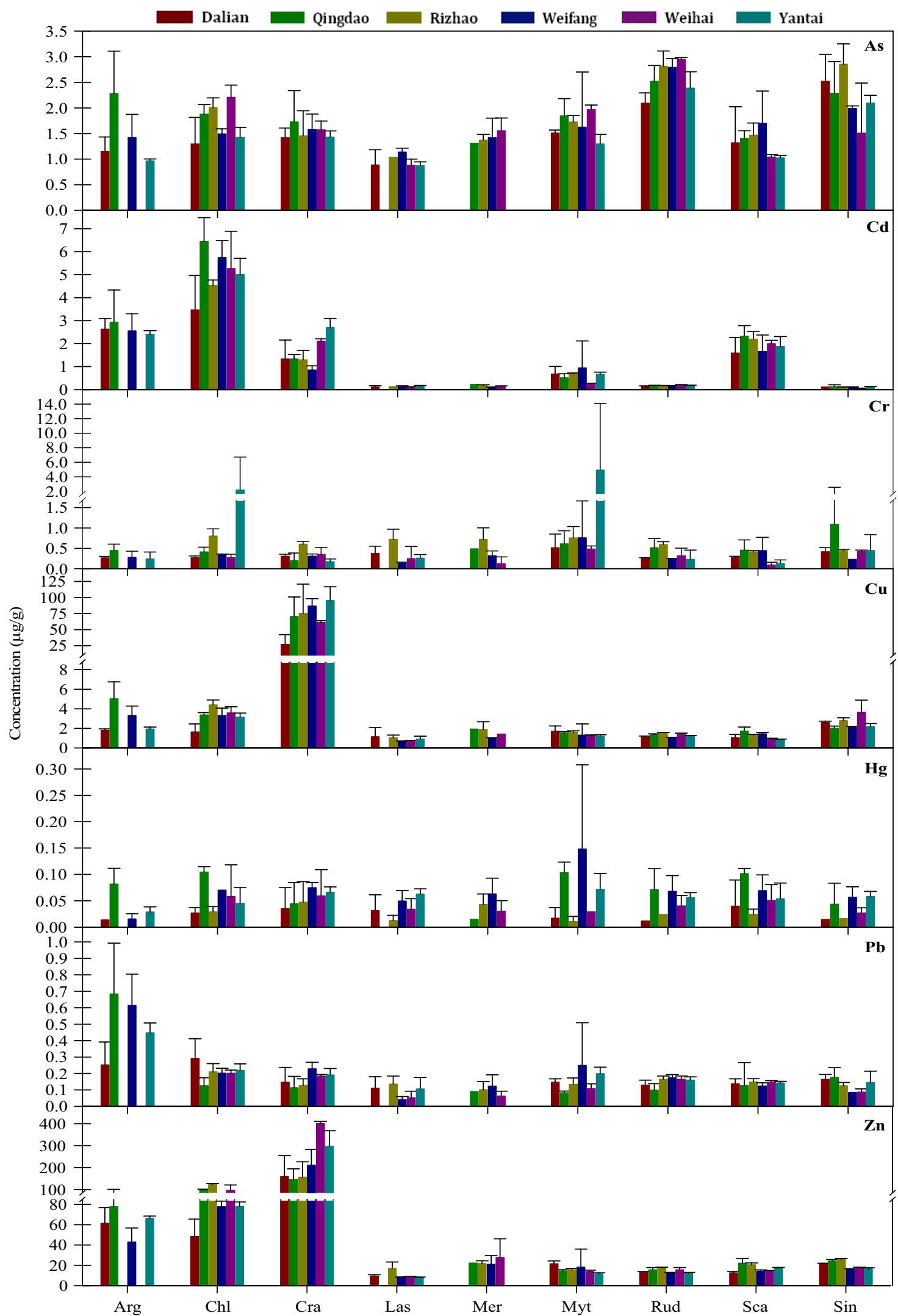

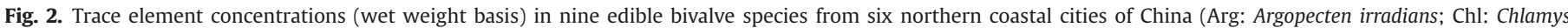

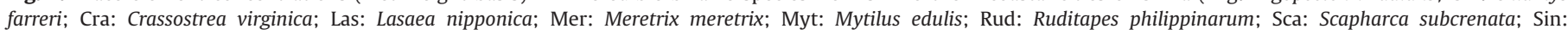
Sinonovacula constricta).

concentration was recorded in M. edulis from Weifang $(0.15 \mu \mathrm{g} / \mathrm{g})$, followed by C. farreri, M. edulis and S. subcrenata from Qingdao $(0.10 \mu \mathrm{g} / \mathrm{g})$.
The $\mathrm{Pb}$ levels in different bivalve species had a narrow range of variation $(0.04-0.68 \mu \mathrm{g} / \mathrm{g})$ and showed an insignificant difference among different locations. The highest level was recorded in 
Table 1

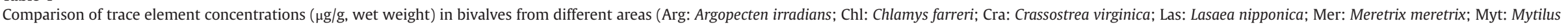
edulis; Rud: Ruditapes philippinarum; Sca: Scapharca subcrenata; Sin: Sinonovacula constricta).

\begin{tabular}{|c|c|c|c|c|c|c|c|c|c|c|c|}
\hline Location & Sampling time & Species & & As & $\mathrm{Cd}$ & $\mathrm{Cr}$ & $\mathrm{Cu}$ & $\mathrm{Hg}$ & $\mathrm{Pb}$ & $\mathrm{Zn}$ & References \\
\hline \multirow[t]{10}{*}{ Cities in the northern coast of China } & \multirow[t]{10}{*}{ Nov. 2011} & $\operatorname{Arg}$ & Range & $0.96-2.28$ & $2.40-2.93$ & $0.24-0.44$ & $1.79-5.01$ & $0.01-0.08$ & $0.25-0.68$ & $42.91-77.61$ & \multirow[t]{10}{*}{ This study } \\
\hline & & Chl & $\begin{array}{l}\text { Mean } \pm \text { SD } \\
\text { Range }\end{array}$ & $\begin{array}{l}1.45 \pm 0.58 \\
1.29-2.20\end{array}$ & $\begin{array}{l}2.63 \pm 0.22 \\
3.47-6.44\end{array}$ & $\begin{array}{l}0.31 \pm 0.09 \\
0.27-2.18\end{array}$ & $\begin{array}{l}3.01 \pm 1.50 \\
1.63-4.39\end{array}$ & $\begin{array}{l}0.03 \pm 0.03 \\
0.03-0.10\end{array}$ & $\begin{array}{l}0.50 \pm 0.19 \\
0.12-0.29\end{array}$ & $\begin{array}{l}61.98 \pm 14.44 \\
48.37-123.47\end{array}$ & \\
\hline & & Cra & $\begin{array}{l}\text { Mean } \pm \text { SD } \\
\text { Range }\end{array}$ & $\begin{array}{l}1.72 \pm 0.36 \\
1.42-1.73\end{array}$ & $\begin{array}{l}5.07 \pm 1.02 \\
0.84-2.69\end{array}$ & $\begin{array}{l}0.71 \pm 0.74 \\
0.17-0.60\end{array}$ & $\begin{array}{l}3.23 \pm 0.90 \\
26.82-95.27\end{array}$ & $\begin{array}{l}0.06 \pm 0.03 \\
0.03-0.07\end{array}$ & $\begin{array}{l}0.21 \pm 0.05 \\
0.11-0.23\end{array}$ & $\begin{array}{l}86.91 \pm 25.24 \\
145.43-401.72\end{array}$ & \\
\hline & & Las & $\begin{array}{l}\text { Mean } \pm \text { SD } \\
\text { Range }\end{array}$ & $\begin{array}{l}1.53 \pm 0.12 \\
0.87-1.13\end{array}$ & $\begin{array}{l}1.60 \pm 0.67 \\
0.08-0.15\end{array}$ & $\begin{array}{l}0.32 \pm 0.15 \\
0.14-0.72\end{array}$ & $\begin{array}{l}69.23 \pm 24.01 \\
0.68-1.14\end{array}$ & $\begin{array}{l}0.05 \pm 0.01 \\
0.01-0.06\end{array}$ & $\begin{array}{l}0.16 \pm 0.04 \\
0.04-0.11\end{array}$ & $\begin{array}{l}228.59 \pm 101.88 \\
7.94-16.93\end{array}$ & \\
\hline & & \multirow[t]{2}{*}{ Mer } & $\begin{array}{l}\text { Mean } \pm S D \\
\text { Range }\end{array}$ & $\begin{array}{l}0.96 \pm 0.12 \\
1.31-1.55\end{array}$ & $\begin{array}{l}0.12 \pm 0.03 \\
0.10-0.22\end{array}$ & $\begin{array}{l}0.35 \pm 0.22 \\
0.12-0.72\end{array}$ & $\begin{array}{l}0.89 \pm 0.20 \\
0.98-1.92\end{array}$ & $\begin{array}{l}0.04 \pm 0.02 \\
0.01-0.06\end{array}$ & $\begin{array}{l}0.09 \pm 0.04 \\
0.06-0.12\end{array}$ & $\begin{array}{l}10.28 \pm 3.75 \\
20.90-27.66\end{array}$ & \\
\hline & & & $\begin{array}{l}\text { Mean } \pm S D \\
\text { Range }\end{array}$ & $\begin{array}{l}1.41 \pm 0.10 \\
1.29-1.97\end{array}$ & $\begin{array}{l}0.15 \pm 0.05 \\
0.25-0.94\end{array}$ & $\begin{array}{l}0.41 \pm 0.26 \\
0.48-4.91\end{array}$ & $\begin{array}{l}1.55 \pm 0.44 \\
1.18-1.70\end{array}$ & $\begin{array}{l}0.04 \pm 0.02 \\
0.01-0.15\end{array}$ & $\begin{array}{l}0.09 \pm 0.02 \\
0.08-0.25\end{array}$ & $\begin{array}{l}23.09 \pm 3.08 \\
11.45-21.52\end{array}$ & \\
\hline & & Myt & $\begin{array}{l}\text { Mean } \pm S D \\
\text { Range }\end{array}$ & $\begin{array}{l}1.66 \pm 0.24 \\
2.09-2.94\end{array}$ & $\begin{array}{l}0.62 \pm 0.23 \\
0.12-0.18\end{array}$ & $\begin{array}{l}1.34 \pm 1.76 \\
0.23-0.59\end{array}$ & $\begin{array}{l}1.42 \pm 0.21 \\
1.06-1.55\end{array}$ & $\begin{array}{l}0.06 \pm 0.05 \\
0.01-0.07\end{array}$ & $\begin{array}{l}0.15 \pm 0.06 \\
0.10-0.17\end{array}$ & $\begin{array}{l}15.85 \pm 3.54 \\
12.34-17.60\end{array}$ & \\
\hline & & Rud & $\begin{array}{l}\text { Mean } \pm S D \\
\text { Range }\end{array}$ & $\begin{array}{l}2.59 \pm 0.32 \\
1.02-1.70\end{array}$ & $\begin{array}{l}0.16 \pm 0.02 \\
1.59-2.32\end{array}$ & $\begin{array}{l}0.36 \pm 0.16 \\
0.09-0.46\end{array}$ & $\begin{array}{l}1.28 \pm 0.18 \\
0.85-1.44\end{array}$ & $\begin{array}{l}0.05 \pm 0.02 \\
0.02-0.10\end{array}$ & $\begin{array}{l}0.15 \pm 0.03 \\
0.12-0.15\end{array}$ & $\begin{array}{l}14.52 \pm 2.00 \\
12.61-21.98\end{array}$ & \\
\hline & & Sca & $\begin{array}{l}\text { Mean } \pm S D \\
\text { Range }\end{array}$ & $\begin{array}{l}1.32 \pm 0.26 \\
1.51-2.85\end{array}$ & $\begin{array}{l}1.93 \pm 0.29 \\
0.04-0.12\end{array}$ & $\begin{array}{l}0.30 \pm 0.16 \\
0.23-1.09\end{array}$ & $\begin{array}{l}1.21 \pm 0.33 \\
2.01-3.64\end{array}$ & $\begin{array}{l}0.06 \pm 0.03 \\
0.01-0.06\end{array}$ & $\begin{array}{l}0.14 \pm 0.01 \\
0.08-0.18\end{array}$ & $\begin{array}{l}16.81 \pm 3.78 \\
16.27-25.83\end{array}$ & \\
\hline & & Sin & $\begin{array}{l}\text { Mean } \pm S D \\
\text { Range }\end{array}$ & $\begin{array}{l}2.21 \pm 0.46 \\
0.87-2.94\end{array}$ & $\begin{array}{l}0.10 \pm 0.03 \\
0.04-6.44\end{array}$ & $\begin{array}{l}0.51 \pm 0.30 \\
0.09-4.91\end{array}$ & $\begin{array}{l}2.55 \pm 0.61 \\
0.68-95.27\end{array}$ & $\begin{array}{l}0.04 \pm 0.02 \\
0.01-0.15\end{array}$ & $\begin{array}{l}0.13 \pm 0.04 \\
0.04-0.68\end{array}$ & $\begin{array}{l}20.31 \pm 4.13 \\
7.94-401.72\end{array}$ & \\
\hline Zhejiang coastline, East China Sea & Aug. 2002 & $\operatorname{Sin}$ & $\begin{array}{l}\text { Mean } \pm \text { SD } \\
\text { Range }\end{array}$ & $\begin{array}{l}1.68 \pm 0.55 \\
0.44-0.81\end{array}$ & $\begin{array}{l}1.40 \pm 1.68 \\
0.05-0.33\end{array}$ & $\begin{array}{l}0.53 \pm 0.72 \\
\mathrm{ND}\end{array}$ & $\begin{array}{l}10.13 \pm 23.63 \\
2.27-9.11\end{array}$ & $\begin{array}{l}0.05 \pm 0.03 \\
0.006- \\
0.021\end{array}$ & $\begin{array}{l}0.17 \pm 0.12 \\
0.06-0.22\end{array}$ & $\begin{array}{l}54.89 \pm 78.02 \\
6.92-17.90\end{array}$ & Huang et al. (2007) \\
\hline Montenegro, SE Adriatic & Sep. 2005-Feb. 2009 & Myt & Range & $0.3-4.1$ & $0.38-0.60$ & ND & $0.6-2.9$ & $0.01-0.17$ & $0.21-2.4$ & $9.9-71.5$ & \multirow{4}{*}{$\begin{array}{l}\text { Stanković et al. (2011) } \\
\text { Liang et al. (2004) }\end{array}$} \\
\hline \multirow[t]{3}{*}{ Bohai Sea } & \multirow[t]{3}{*}{ Jul.-Aug. 2002} & $\mathrm{Cra}$ & Range & ND & $0.51-3.29$ & ND & $25.24-109.60$ & ND & $0.21-0.62$ & $115.95-379.55$ & \\
\hline & & Myt & Range & ND & $0.34-1.96$ & ND & $1.16-2.52$ & ND & $0.16-0.60$ & $11.87-22.42$ & \\
\hline & & Rud & Range & ND & $0.14-0.63$ & ND & $1.28-2.60$ & ND & $0.13-0.34$ & $9.95-20.06$ & \\
\hline \multirow[t]{5}{*}{ Bohai Sea } & \multirow[t]{5}{*}{ Jul.-Aug. 2003} & $\mathrm{Cra}$ & Range & $1.04-2.16$ & $0.94-32.18$ & $0.21-0.66$ & $34.69-146.85$ & $0.01-0.04$ & $0.05-0.52$ & $141.86-550.12$ & \multirow[t]{5}{*}{ Wang et al. (2005) } \\
\hline & & Mer & Range & $0.90-1.78$ & $0.17-0.70$ & $0.17-0.30$ & $1.69-33.83$ & $0.02-0.02$ & $0.06-1.33$ & $22.21-53.97$ & \\
\hline & & Myt & Range & $0.92-4.97$ & $0.17-1.29$ & $0.18-0.67$ & $0.98-5.40$ & $0.01-0.03$ & $0.09-0.59$ & $9.76-42.17$ & \\
\hline & & Rud & Range & $1.98-2.85$ & $0.14-0.29$ & $0.16-0.35$ & $1.44-3.56$ & $0.02-0.04$ & $0.08-0.28$ & $10.84-32.38$ & \\
\hline & & Sca & Range & $0.84-2.55$ & $1.40-12.84$ & $0.13-0.44$ & $1.08-4.45$ & $0.01-0.03$ & $0.08-0.45$ & $11.56-30.59$ & \\
\hline The north-western Mediterranean ${ }^{\mathrm{a}}$ & Summer 2004 and 2005 & Myt & Range & ND & $0.23-0.36$ & $0.09-0.60$ & ND & $0.018-0.024$ & $0.21-0.29$ & ND & Lafabrie et al. (2007) \\
\hline \multirow[t]{2}{*}{ The northern China seas } & \multirow[t]{2}{*}{ Oct.-Nov. 2005} & $\operatorname{Arg}$ & Range & $0.18-0.42$ & ND & ND & $1.38-4.41$ & $\begin{array}{l}0.006- \\
0.021\end{array}$ & $0.06-0.17$ & $42.51-92.34$ & \multirow[t]{2}{*}{ Wang et al. (2007) } \\
\hline & & $\mathrm{Chl}$ & Range & $0.27-0.50$ & ND & ND & $2.29-10.25$ & $0.014-0.023$ & $0.11-0.25$ & $81.29-209.72$ & \\
\hline The Bay of Islands, northern New Zealand & Dec. 2005 & Myt & Range & $1.56-2.97$ & $0.07-0.75$ & ND & ND & $0.04-0.06$ & $0.03-0.10$ & ND & Whyte et al. (2009) \\
\hline Bohai Sea & Summer & Mussel & Range & $0.29-12.15$ & $0.27-6.50$ & ND & ND & $0.006-0.108$ & $\begin{array}{l}0.033- \\
0.895\end{array}$ & ND & Liu et al. (2007) \\
\hline Fish markets in and around Cochin, India & Jul. 2003-Jan. 2005 & Myt & Range & BDL-0.69 & BDL-0.98 & $0.18-3.65$ & $1.17-24.1$ & BDL-0.33 & BDL-0.98 & $3.8-37.7$ & Sivaperumal et al. (2007) \\
\hline \multirow{4}{*}{ Shellfish culture areas of Xiamen } & \multirow{4}{*}{ Apr. 2005} & $\mathrm{Cra}$ & Range & $\mathrm{ND}$ & $0.38-0.72$ & ND & $20.9-60.3$ & $\mathrm{ND}$ & $0.20-0.37$ & $90.0-163.5$ & \multirow{4}{*}{ Ruan (2008) } \\
\hline & & Rud & Range & ND & $0.11-0.35$ & ND & $1.02-2.26$ & ND & $0.09-0.28$ & $12.4-17.9$ & \\
\hline & & $\operatorname{Sin}$ & Range & ND & $0.04-0.05$ & ND & $2.69-4.39$ & ND & $0.26-0.48$ & $14.6-20.0$ & \\
\hline & & $\begin{array}{l}\text { Tegillarca } \\
\text { granosa }\end{array}$ & Range & ND & $1.14-1.16$ & ND & $0.88-0.97$ & ND & $0.20-0.22$ & $15.5-17.3$ & \\
\hline
\end{tabular}

ND: no data.

BDL: below detection limit.

a The values have been converted to wet weight contents (calculated as $80 \%$ water content). 
A. irradians from Qingdao, followed by A. irradians from Weifang $(0.61 \mu \mathrm{g} / \mathrm{g})$. Our results were consistent with previous measurements of bivalves $(0.033-1.43 \mu \mathrm{g} / \mathrm{g}$ ) (Lafabrie et al., 2007; Liu et al., 2007; Wang et al., 2007; Whyte et al., 2009). The Pb levels in all the collected edible bivalve species were all below the restrictive concentration $(1.5 \mu \mathrm{g} / \mathrm{g}$ wet weight) set up by the EC (European Commission) (2006).

The concentrations of $\mathrm{Zn}$ in different bivalve species had a wide range of variation $(7.94-401.72 \mu \mathrm{g} / \mathrm{g})$ and showed a significant difference among different sampled cities. The results were rather comparable to the earlier observations on bivalves $(2.51-379.55 \mu \mathrm{g} / \mathrm{g}$ ) (Sivaperumal et al., 2007; Wang et al., 2007; Ruan, 2008). The Zn levels in all studied species were all within the restrictive range (inorganic As $1.0 \mu \mathrm{g} / \mathrm{g}$ wet weight) set up by the WHO (WHO, 1982). The concentrations of $\mathrm{Zn}$ in L. nipponica, M. meretrix, M. edulis, R. philippinarum, S. subcrenata and S. constricta from the sampled cities varied within relatively narrower ranges and the mean values of $\mathrm{Zn}$ in these species were apparently lower than in A. irradians, $C$. farreri and C. gigas. The highest $\mathrm{Zn}$ concentration $(401.72 \mu \mathrm{g} / \mathrm{g})$ was recorded in $C$. gigas from Weihai, which was about 50 times higher than the lowest $\mathrm{Zn}$ level $(7.94 \mu \mathrm{g} / \mathrm{g})$ of L. nipponica from Yantai. C. gigas from Yantai exhibited the second highest $\mathrm{Zn}$ concentration $(297.13 \mu \mathrm{g} / \mathrm{g})$ which was comparable with other areas. The concentrations of $\mathrm{Zn}$ in some species (C. gigas from all the sampled cities and C. farreri from Rizhao) exceeded the maximum permissible levels of $100 \mu \mathrm{g} / \mathrm{g}$ wet weight set up by the WHO (1982).

In general, among different bivalve species from different locations, $\mathrm{Zn}$ had the highest concentrations, followed by $\mathrm{Cu}, \mathrm{As}$, $\mathrm{Cd}, \mathrm{Cr}$, and $\mathrm{Pb}$, while the $\mathrm{Hg}$ levels were the lowest. There were no clear spatial differences among locations for any studied trace element. Two possibilities may explain such a lack of spatial patterns. First, there was probably no obvious source of trace metal input. Second, some of these trace elements (e.g. $\mathrm{Cu}$ and $\mathrm{Zn}$ ) are essential to marine animals, and it is likely that these elements may be regulated by the bivalves during the processes of their bioaccumulation. For example, the regulation of $\mathrm{Cd}, \mathrm{Cu}$, and $\mathrm{Zn}$ by bivalves has been demonstrated by previous studies (Blackmore and Wang, 2003; Pan and Wang, 2009). Information concerning whether bivalves can regulate $\mathrm{Hg}$ uptake is still not available.

A further comparison of the data obtained in this study with those previously reported indicates that the levels of trace elements found in bivalves are comparable to those reported for other areas home and abroad (Table 1 ).

It was reported that the concentrations of $\mathrm{As}, \mathrm{Cd}, \mathrm{Cr}, \mathrm{Cu}, \mathrm{Hg}, \mathrm{Pb}$, and $\mathrm{Zn}$ in marine bivalves from the Bohai Sea in northern China were generally within the range of $0.84-4.97 \mu \mathrm{g} / \mathrm{g}, 0.14-32.18 \mu \mathrm{g} /$ g, 0.13-0.67 $\mu \mathrm{g} / \mathrm{g}, 0.98-146.85 \mu \mathrm{g} / \mathrm{g}, 0.01-0.04 \mu \mathrm{g} / \mathrm{g}, 0.05-1.33 \mu \mathrm{g} /$ $\mathrm{g}$, and 9.76-550.12 $\mu \mathrm{g} / \mathrm{g}$, respectively (Liang et al., 2004; Wang et al., 2005). Our measurements of the bivalves consumed in the six northern coastal cities of China showed that the values obtained herein fell within the range of values commonly found in the previous measurements. The data of $M$. edulis in this study were rather similar to the previous measurements (e.g. $0.92-4.97 \mu \mathrm{g} / \mathrm{g}$ As, 0.17-1.29 $\mu \mathrm{g} / \mathrm{g} \mathrm{Cd}, 0.98-5.40 \mu \mathrm{g} / \mathrm{g} \mathrm{Cu}, 0.01-0.03 \mu \mathrm{g} / \mathrm{g} \mathrm{Hg}, 0.09-$ $0.59 \mu \mathrm{g} / \mathrm{g} \mathrm{Pb}, 9.76-42.17 \mu \mathrm{g} / \mathrm{g} \mathrm{Zn}$ from the Bohai Sea; 0.38$0.60 \mu \mathrm{g} / \mathrm{g} \mathrm{Cd}, 0.01-0.17 \mu \mathrm{g} / \mathrm{g} \mathrm{Hg}$, and 9.95-379.55 $\mu \mathrm{g} / \mathrm{g} \mathrm{Zn}$ from Montenegro, SE Adriatic) (Wang et al., 2005; Stanković et al., 2011). It could be found from Table 1 that the trace element contents in $C$. gigas at different sampling time and cities varied slightly except Cd contents. It was once up to $32.18 \mu \mathrm{g} / \mathrm{g}$, indicating a severe Cd contamination status in the Bohai Sea at that time (Liang et al., 2004; Wang et al., 2005). Meanwhile, we found the trace element concentrations in $R$. philippinarum, S. subcrenata, and $S$. constricta in this study did not differ greatly from the previous reports of Liang et al. (2004), Wang et al. (2005) and
Huang et al. (2007). In general, the levels of trace elements found in bivalves collected from the local seafood markets in the northern coastal cities of China were not very high and the contamination was moderate.

\subsection{One-way ANOVA analysis and inter-elemental relationships in view of correlation}

Significant differences in trace element concentrations were tested with one-way ANOVA for each species and for each trace element for the investigated samples. Table S2 shows the ANOVA results. Differences in trace element concentrations were found among the studied species. For example, C. gigas significantly accumulated $\mathrm{Cu}$ and $\mathrm{Zn}$, while $M$. edulis accumulated $\mathrm{Cr}$ and $\mathrm{Hg}$ more efficiently than other bivalves. Similarly, a trace element can be accumulated by different bivalves. For example, As can be significantly accumulated by $R$. philippinarum and $S$. constricta. Results of correlation analyses (bivariate correlations with Pearson correlations coefficients) among these trace element concentrations are listed in Table S3 $(P<0.05$ or $P<0.01)$. Cd was significantly correlated with $\mathrm{Pb}$ and $\mathrm{Zn}(P<0.01)$, while $\mathrm{Cu}$ was correlated with $\mathrm{Zn}(P<0.01)$. There were also some correlations between $\mathrm{Cd}$ and $\mathrm{Hg}(P<0.05)$.

To obtain a visual representation of spatial and interspecific variations among these trace element concentrations in the bivalve species, cluster analysis was performed based on the analytical data by the XLSTAT software. All the investigated samples could be grouped in terms of their similarity. The results obtained following hierarchical cluster analysis are shown as a dendrogram (Fig. 3) in which three well-defined clusters can be seen. A group of samples can be clearly discernible which is composed of adherent, benthic and sessile bivalves (YT-Chl, WH-Chl, WF-Chl, RZ-Chl, QD-Sca, DL-Arg, QD-Chl, DL-Chl, YT-Arg, WH-Sca, YT-Sca, WF-Sca, DL-Sca, RZ-Sca, YT-Cra, QD-Arg, WF-Arg, WF-Myt, WH-Mer, WH-Cra, WF-Cra, RZ-Cra, QD-Cra, DL-Cra and DL-Myt); There was no geographic variation in trace element concentrations in $C$. farreri and S. subcrenata with the similarity of 85 percent. At the same time, no geographic differences were found in $C$. gigas with the similarity of 90 percent. $\mathrm{Zn}$ and $\mathrm{Cu}$ made the greatest contribution (more than 98 percent) to the average similarity of 76.78 percent for $C$. gigas (Table S4). This is in agreement with the results of the trace element concentrations and $C$. gigas samples lay at some distance from the others. The second cluster consists of adherent bivalves (YT-Myt) alone because of the highest $\mathrm{Cr}$ levels in M. edulis from Yantai. The third cluster includes the rest ones which mainly belonged to adherent and sessile bivalves. $R$. philippinarum exhibited no geographic variation in trace element concentrations with the similarity of 90 percent. Comparable trace element levels in $R$. philippinarum samples may account for this. $\mathrm{Zn}$ and As made the contribution (88.83 percent, 92.88 percent, 85.94 percent) to the average similarity for $L$. nipponica (84.10 percent), M. meretrix (91.67 percent) and $M$. edulis (84.07 percent) (Table S4). Zn and Cd contributed more than 90 percent (93.43 percent, 94.08 percent) to the average similarity for scallops (84.42 percent for $A$. irradians, 82.04 percent for $C$. farreri) (Table S4). Moreover, the similarity (more than 90 percent for C. gigas, R. philippinarum and S. constricta; more than 85 percent for C. farreri and S. subcrenata) for the enrichment of trace elements indicated no significant difference among different locations. It is possible that the first cluster and the third cluster were well separated due to the variations in the bioaccumulation of trace elements between them. Assimilation efficiency, feeding activity (filtration rate), and efflux rate co-contributed to the observed interspecies differences which may explain such a phenomenon. The importance of efflux rate to intraspecies difference in $\mathrm{Cu}$ bioaccumulation has been demonstrated by the previous study (Pan and Wang, 2009). 


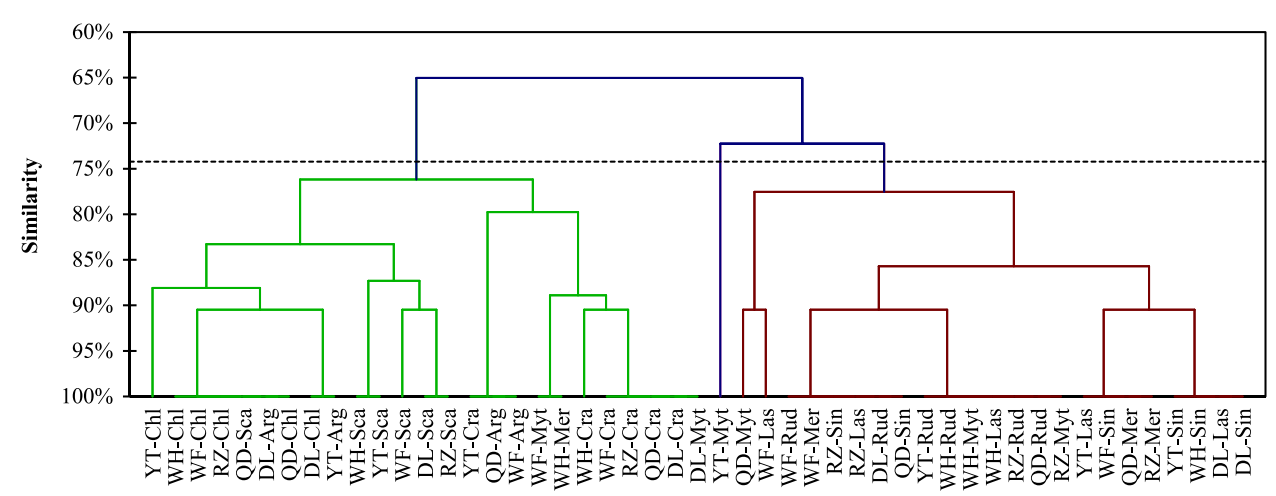

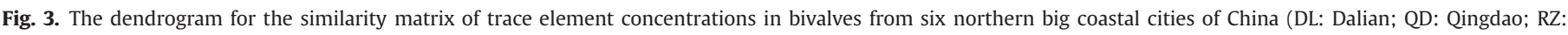

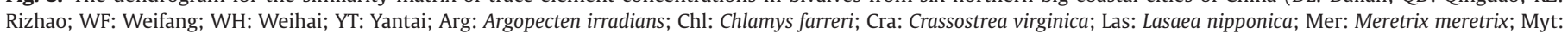
Mytilus edulis; Rud: Ruditapes philippinarum; Sca: Scapharca subcrenata; Sin: Sinonovacula constricta).

\subsection{Assessment of human exposure to trace elements}

The element As exists in organisms in both organic and inorganic forms. According to most criteria for the amounts of trace elements in food, the concentration of inorganic As should be more restricted because it is more toxic than organic As. The results of As in this study were the sum of organic and inorganic As. The inorganic fraction was estimated by multiplying the As concentrations in this study by 10 percent according to the guidance document for arsenic in shellfish of the USFDA (United States Food and Drug Administration) (1993). As shown in Table 1, the concentrations of $\mathrm{As}, \mathrm{Hg}$, and $\mathrm{Pb}$ in all the collected edible bivalve species were all within the restrictive range (inorganic As $1.0, \mathrm{Hg} 0.3, \mathrm{~Pb} 1.5 \mu \mathrm{g} / \mathrm{g}$ wet weight) set up by the AQSIQ (General Administration of Quality Supervision, Inspection and Quarantine of the People's Republic of China) (2001), EC (European Commission) (2006). However, Cd, Cu, and $\mathrm{Zn}$ exhibited apparent differences in different bivalve species (Fig. 2). Meanwhile, the $\mathrm{Cu}$ and $\mathrm{Zn}$ levels were extraordinarily high in all the collected $C$. gigas except those from Dalian and exceeded the maximum permissible levels (MPLs; Cu 50 and $\mathrm{Zn} 100 \mu \mathrm{g} / \mathrm{g}$ wet weight) set up by the AQSIQ (General Administration of Quality Supervision, Inspection and Quarantine of the People's Republic of China) (2001) and the WHO (1982), and the Cd content in those from Weihai and Yantai exceeded the restrictive value of $\mathrm{Cd}(2 \mu \mathrm{g} / \mathrm{g}$ wet weight) set up by the WHO (1982). Disturbingly, the Cd contents in $A$. irradians and $C$. farreri from all the studied cities exceeded the MPL set up by the WHO (1982). Obviously these three kinds of bivalves were not suitable for long-term consumption unless they are previously depurated to reduce the high levels of trace elements (Han and Hung, 1990; Chan et al., 1999).

In the present study, the estimated amount of daily bivalve consumption of $20 \mathrm{~g}$ wet weight/person/day in China (FAO, 2011; BFMAC (Bureau of Fisheries of the Ministry of Agriculture of China), 2012) and an assumed body weight of $58.1 \mathrm{~kg}$ for a Chinese person ( $\mathrm{Gu}$ et al., 2006) were used to evaluate daily intake of the investigated elements by people in northern China through bivalve consumption. As shown in Table $\mathrm{S} 5$, the EDI of all trace elements except Cd by people were far below the $A D I$ recommended by the $\mathrm{FAO} / \mathrm{WHO}$, indicating this intake would not pose a health risk in northern China at present. For $\mathrm{Cd}$, this intake would pose a potential health risk for people in northern China. The RfDs were $0.3 \mu \mathrm{g} / \mathrm{kg}$ bw/day for inorganic As, $1 \mu \mathrm{g} / \mathrm{kg}$ bw/day for Cd, $3 \mu \mathrm{g} / \mathrm{kg}$ bw/day for $\mathrm{Cr}, 40 \mu \mathrm{g} / \mathrm{kg}$ bw/ day for $\mathrm{Cu}, 0.1 \mu \mathrm{g} / \mathrm{kg}$ bw/day for $\mathrm{Hg}, 300 \mu \mathrm{g} / \mathrm{kg}$ bw/day for $\mathrm{Zn}$, respectively (USEPA (United States Environmental Protection Agency), 2011). Our calculations suggested that the HQs of all trace elements examined in all studied bivalve species from all sampled cities except Cd in A. irradians from Qingdao and $C$. farreri from all sampled cities (excluding $\mathrm{Pb}$, which does not have an agreed $R f D$ value) were significantly less than one in this study, suggesting an overall situation that the consumption of most bivalve species at current levels does not present any risk of excessive trace element intake to people (Table 2). The calculated EDI of bivalve species suggested the consumption levels for some trace elements ( $\mathrm{As}, \mathrm{Cr}, \mathrm{Hg}, \mathrm{Pb}$ and $\mathrm{Zn}$ ) were $~ 3-$ 110 times lower than the corresponding RfD guidelines, and people would not experience significant health risks from the intake of trace elements through bivalve consumption. But the calculated EDI values of $\mathrm{Cd}$ and $\mathrm{Cu}$ were $\sim 0.8-2.2$ times higher than the corresponding RfD guidelines, and people could experience significant health risks from the intake of these trace elements through bivalve consumption.

\subsection{Estimated daily intake of trace elements via bivalve consumption}

In this study, the PTWI values were used for the calculation of the trace element concentrations associated with the consumption of investigated bivalves collected from the studied areas. As there are no data on the average national rate of bivalve consumption in China, the PTWI values were employed as the standards for the calculation of the trace element levels associated with possible amounts of bivalve consumed.

FAO/WHO Expert Committee on Food Additives have set a PTWI of inorganic As (As*) as $15 \mu \mathrm{g} / \mathrm{kg}$ bw/week, a PTWI of Cd as $7 \mu \mathrm{g} / \mathrm{kg}$ bw/week, a PTWI of Cu as $500 \mu \mathrm{g} / \mathrm{kg}$ bw/week, a PTWI of total $\mathrm{Hg}$ as $5 \mu \mathrm{g} / \mathrm{kg}$ bw/week, a PTWI of Pb as $25 \mu \mathrm{g} / \mathrm{kg}$ bw/week, a PTWI of $\mathrm{Zn}$ as $2100 \mu \mathrm{g} / \mathrm{kg}$ bw/week for human beings (JECFA (Joint FAO/ WHO Expert Committee on Food Additives), 1989; FAO/WHO (Food Additive Organization of the United Nations and World Health Organization), 2004). Based on these data, for normal adult Chinese people ( $58.1 \mathrm{~kg}$ body weight), a daily consumption of $423-$ 1102 g, 9-485 g, 44-3640 g, 277-692 g, 71-184 g, 145-3432 g wet weight edible tissues of different bivalves is sufficient to reach the PTWI limit for As* (0.87 mg/person/week), Cd (0.41 mg/person/ week), Cu (29.05 mg/person/week), $\mathrm{Hg}$ (0.29 mg/person/week), Pb (1.45 mg/person/week), Zn (406.7 mg/person/week), respectively (Table 3). On the whole, for all the sampled cities, As and $\mathrm{Hg}$ in all the studied species and $\mathrm{Cu}$ and $\mathrm{Zn}$ in all the studied species except C. gigas posed low risks to human health based on the calculated daily intake amounts presented in Table 3, which were large enough compared with the normal appetite of people; Cd and $\mathrm{Pb}$ in some species for all the sampled cities or some of the sampled cities posed high risks to human health.

For Cd, the calculated daily intake amounts were 20-24 g wet weight/day for A. irradians, 9-17 g wet weight/day for C. farreri, 
Table 2

The calculated hazard quotients.

\begin{tabular}{|c|c|c|c|c|c|c|c|}
\hline Species & $\mathrm{As}^{* a}$ & $\mathrm{Cd}$ & $\mathrm{Cr}$ & $\mathrm{Cu}$ & $\mathrm{Hg}$ & $\mathrm{Pb}$ & $\mathrm{Zn}$ \\
\hline Argopecten irradians & $0.11-0.26$ & $0.82-1.00$ & $0.03-0.05$ & $0.02-0.04$ & $0.03-0.27$ & $\mathrm{ND}^{\mathrm{b}}$ & $0.05-0.09$ \\
\hline Chlamys farreri & $0.15-0.25$ & $1.19-2.20$ & $0.03-0.25$ & $0.01-0.04$ & $0.10-0.34$ & ND & $0.06-0.14$ \\
\hline Crassostrea gigas & $0.16-0.20$ & $0.29-0.92$ & $0.02-0.07$ & $0.23-0.81$ & $0.10-0.24$ & ND & $0.17-0.46$ \\
\hline Lasaea nipponica & $0.10-0.13$ & $0.03-0.05$ & $0.02-0.08$ & $<0.01-0.10$ & $0.03-0.21$ & ND & $0.01-0.02$ \\
\hline Meretrix meretrix & $0.15-0.18$ & $0.03-0.08$ & $0.01-0.08$ & $<0.01-0.02$ & $0.03-0.21$ & ND & $0.02-0.03$ \\
\hline Mytilus edulis & $0.15-0.22$ & $0.09-0.32$ & $0.06-0.56$ & $0.01-0.02$ & $0.03-0.51$ & ND & $0.01-0.02$ \\
\hline Ruditapes philippinarum & $0.24-0.34$ & $0.04-0.06$ & $0.03-0.07$ & $<0.01-0.01$ & $0.03-0.24$ & ND & $0.01-0.02$ \\
\hline Scapharca subcrenata & $0.12-0.19$ & $0.54-0.79$ & $0.01-0.05$ & $<0.01-0.01$ & $0.07-0.34$ & ND & $0.01-0.03$ \\
\hline Sinonovacula constricta & $0.17-0.32$ & $0.01-0.04$ & $0.03-0.12$ & $0.02-0.03$ & $0.03-0.21$ & ND & $0.02-0.03$ \\
\hline
\end{tabular}

a As*: the concentration of inorganic As which was estimated as $10 \%$ of the total As concentration (USFDA (United States Food and Drug Administration), 1993).

${ }^{\mathrm{b}} \mathrm{ND}$ : no data.

Table 3

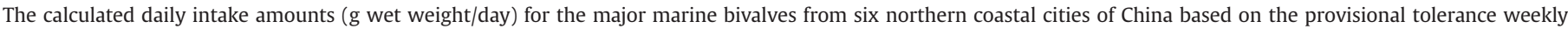
intake of trace elements.

\begin{tabular}{|c|c|c|c|c|c|c|c|}
\hline Species & $\mathrm{As}^{* \mathrm{a}}$ & $\mathrm{Cd}$ & $\mathrm{Cr}$ & $\mathrm{Cu}$ & $\mathrm{Hg}$ & $\mathrm{Pb}$ & $\mathrm{Zn}$ \\
\hline Argopecten irradians & $546-1297$ & $20-24$ & $\mathrm{ND}^{\mathrm{b}}$ & $828-2318$ & $519-4150$ & $91-216$ & $749-1354$ \\
\hline Chlamys farreri & $566-965$ & $9-17$ & ND & $945-2546$ & $415-1383$ & $94-161$ & $471-1201$ \\
\hline Crassostrea gigas & $720-877$ & $22-69$ & ND & 44-155 & $593-1383$ & $120-146$ & $145-400$ \\
\hline Lasaea nipponica & $1102-1431$ & $388-727$ & ND & $3640-6103$ & $692-4150$ & $184-239$ & $3432-7317$ \\
\hline Meretrix meretrix & $803-950$ & $264-581$ & ND & $2161-4235$ & $692-4150$ & $134-158$ & $2101-2780$ \\
\hline Mytilus edulis & $632-965$ & $62-233$ & ND & $2441-3517$ & $277-4150$ & $105-161$ & $2700-5074$ \\
\hline Ruditapes philippinarum & $423-596$ & $323-485$ & ND & 2677-3915 & $593-4150$ & $71-99$ & $3301-4708$ \\
\hline Scapharca subcrenata & $732-1221$ & $25-37$ & ND & $2882-4882$ & $415-2075$ & $122-203$ & $2643-4607$ \\
\hline Sinonovacula constricta & $437-825$ & $485-1454$ & ND & 1140-2065 & $692-4150$ & $73-137$ & 2249-3571 \\
\hline
\end{tabular}

a As*: the concentration of inorganic As which was estimated as 10\% of the total As concentration (USFDA (United States Food and Drug Administration), 1993).

${ }^{b}$ ND: no data.

22-69 g wet weight/day for C. gigas, and 25-37 g wet weight/day for $S$. subcrenata. These results were consistent with high Cd levels of these three bivalves. The Cd concentrations in bivalve species ( $A$. irradians and $C$. farreri from all the studied cities, S. subcrenata from Qingdao and Rizhao) exceeding the MPL may account for this. C. farreri with significantly accumulated Cd contributed more to the less daily intake amounts than other bivalve species. Disturbingly, Cd in C. farreri from all the studied cities, especially from Qingdao could pose a potential leaching risk to human health.

For $\mathrm{Cu}$ and $\mathrm{Zn}$, the calculated daily intake amounts were 44-155 g wet weight/day and 145-400 g wet weight/day for C. gigas. Significantly accumulated $\mathrm{Cu}$ and $\mathrm{Zn}$ would allow only very restricted daily intake amounts for $C$. gigas. $\mathrm{Cu}$ and $\mathrm{Zn}$ in all the collected C. gigas (except $\mathrm{Cu}$ in $C$. gigas from Dalian) exceeded the MPLs set up by the AQSIQ and WHO. In particular, over consumption of $C$. gigas from Yantai may put people in danger with excessive intake of $\mathrm{Cu}$.

A daily consumption of as low as 9 and $94 \mathrm{~g}$ of $C$. farreri is sufficient for $\mathrm{Cd}$ and $\mathrm{Pb}$ to reach the PTWI limits, respectively, which is the amount that may result in a risky weekly intake of Cd and $\mathrm{Pb}$ if the exposure is long-term. In terms of the studied trace elements, especially $\mathrm{Cd}$ daily consumption would be the limiting factor for bivalves as a food for a large number of consumers and coastal residents from the six northern coastal cities of China. Besides, care must be taken considering that most coastal residents regularly consume large quantities of bivalves.

\section{Conclusion}

Accumulation of trace elements (such as As, $\mathrm{Cd}, \mathrm{Cr}, \mathrm{Hg}, \mathrm{Pb}$ ) in food is a major health safety concern worldwide. The present study was a large-scale investigation of trace elements in nine edible bivalve species from six northern coastal cities of China. The results indicated that trace element levels varied in different bivalve species, possibly due to the differences in trace element bioaccumulation. The concentrations of the essential trace elements were higher than those of the non-essential trace elements, with $\mathrm{Zn}$ concentrations being the highest. There were significant correlations between some elements ( $\mathrm{Cd}-\mathrm{Pb}, \mathrm{Cd}-\mathrm{Zn}, \mathrm{Cu}-\mathrm{Zn})$. Risk assessments indicated that we should pay attention to human health risks associated with the exposure to $\mathrm{Cd}$ and $\mathrm{Cu}$ via the consumption of marketed bivalves. Human health risks associated with the exposure to the other studied trace elements through the consumption of marketed bivalves were negligible. However, care must be taken considering that most coastal residents regularly consume large quantities of bivalves.

\section{Acknowledgments}

This study was co-supported by the Department of Science and Technology of Shandong Province (2012GHY11535) and the CAS/ SAFEA International Partnership Program for Creative Research Teams (Representative Environmental Processes and Their Effects on the Resources in Coastal Zone). The help of Drs. Boquan Li and Qingxi Han in the identification of sampled bivalve species is greatly appreciated.

\section{Appendix A. Supporting information}

Supplementary data associated with this article can be found in the online version at http://dx.doi.org/10.1016/j.ecoenv.2014.07.023. 


\section{References}

AQSIQ (General Administration of Quality Supervision, Inspection and Quarantine of the People's Republic of China), 2001. Safety Qualification for Agricultural Product-Safety Requirements for Non-environmental Pollution Aquatic Products (GB 18406.4-2001)

Australian Agency for International Development, 1996. Country Environmental Profile of China. Commonwealth of Australia, Canberra, Australia p. 115.

BFMAC (Bureau of Fisheries of the Ministry of Agriculture of China), 2012. China Fishery Statistical Yearbook 2011. China Agriculture Press, Beijing p. 138.

Blackmore, G., Wang, W.X., 2003. Comparison of metal accumulation in mussels at different local and global scales. Environ. Toxicol. Chem. 22, 388-395.

Capelli, R., Drava, G., De Pellegrini, R., Minganti, V., Poggi, R., 2000. Study of trace elements in organs and tissues of striped dolphins (Stenella coeruleoalba) found dead along the Ligurian coasts (Italy). Adv. Environ. Res. 4, 31-43.

Chan, K.W., Cheung, R.Y.H., Leung, S.F., Wong, M.H., 1999. Depuration of metals from soft tissues of oysters (Crassostrea gigas) transplanted from a contaminated site to clean sites. Environ. Pollut. 105, 299-310.

Du, R.X., Fan, Z.X., Wen, A.L., Cai, L.J., Zhang, B., 2009. Content analysis of heavy metal in economic shellfish from Shandong coast. (In Chinese). Shandong Agric Sci. 8, 58-63.

EC (European Commission), 2006. Commission Regulation (EC) No. 1881/2006 of 19 December 2006 setting maximum levels for certain contaminants in foodstuffs. Official Journal of the European Union L 364, pp. 5-24.

FAO (Food and Agricultural Organization of the United Nations), 2011. Food Supply -Livestock and Fish Primary Equivalent. FAOSTAT. 〈http://faostat3.fao.org/ faostat-gateway/go/to/download/FB/CL/E

FAO (Food and Agriculture Organization of the United Nations), 2012. The State of World Fisheries and Aquaculture 2012. Rome, Italy, 209p.

FAO/WHO (Food Additive Organization of the United Nations and World Health Organization), 2004. Summary Evaluations Performed by the Joint FAO/WHO Expert Committee on Food Additives (JECFA 1956-2003). Internet Edition. ILSI Press, Washington, DC $\langle$ http://jecfa.ilsi.org $\rangle$.

Gao, X.L, Zhou, FX, Chen, CTA, 2014. Pollution status of the Bohai Sea: an overview of the environmental quality assessment related trace metals. Environ. Int. 62, 12-30.

Gu, D.F., He, J., Duan, X.F., Reynolds, K., Wu, X.G., Chen, J., Huang, G.Y., Chen, C.S Whelton, P.K. 2006. Body weight and mortality among men and women in China. J. Am. Med. Dir. Assoc. 295, 776-783.

Han, B.C., Hung, T.C., 1990. Green oysters caused by copper pollution on the Taiwan coast. Environ. Pollut. 5, 347-362.

Huang, H., Wu, J.Y., Wu, J.H., 2007. Heavy metal monitoring using bivalved shellfish from Zhejiang coastal waters, East China Sea. Environ. Monit. Assess. 129, $315-320$.

Jacinto, G.S., 1997. Preliminary assessment of marine pollution issues in the East Asian Seas region at the end of the millennium. Trop. Coasts 4, 3-7.

JECFA (Joint FAO/WHO Expert Committee on Food Additives), 1989. WHO Technica Report Series 759, WHO, Geneva, Switzerland.

JECFA (Joint FAO/WHO Expert Committee on Food Additives), 2003. Summary and Conclusions of the 61st Meeting of the Joint FAO/WHO Expert Committee on Food Additives, JECFA/61/Sc, Rome, Italy, 10-19.06.03, pp. 1-22.

Lafabrie, C., Pergent, G., Kantin, R., Pergent-Martini, C., Gonzalez, J.L., 2007. Trace metals assessment in water, sediment, mussel and seagrass species-validation of the use of Posidonia oceanica as a metal biomonitor. Chemosphere 68, 2033-2039.
Liang, L.N., He, B., Jiang, G.B., Chen, D.Y., Yao, Z.W., 2004. Evaluation of mollusks as biomonitors to investigate heavy metal contaminations along the Chinese Bohai Sea. Sci. Total Environ. 324, 105-113.

Liu, W.X., Chen, J.L., Lin, X.M., Fan, Y.S., Tao, S., 2007. Residual concentrations of micropollutants in benthic mussels in the coastal areas of Bohai Sea, North China. Environ. Pollut. 146, 470-477.

Pan, K., Wang, W.X., 2009. Biodynamics to explain the difference of copper body concentrations in five marine bivalve species. Environ. Sci. Technol. 43, 2137-2143.

Rawson, P.D., Burton, R.S., 2002. Functional coadaptation between cytochrome c and cytochrome $c$ oxidase within allopatric populations of a marine copepod. Proc. Nat. Acad. Sci. U.S.A. 99, 12955-12958.

Ruan, J.S., 2008. A preliminary study of heavy metal contents in sea water, sediments and cultured shellfish in shellfish culture areas of Xiamen (In Chinese). J. Trop. Oceanogr. 27 (5), 47-54.

Sivaperumal, P., Sankar, T.V., Viswanathan Nair, P.G., 2007. Heavy metal concentrations in fish, shellfish and fish products from internal markets of India vis-a-vis international standards. Food Chem. 102 (3), 612-620.

Stanković, S. Jovic, M., Milanov, R., Joksimovic, D., 2011. Trace elements concentrations $(\mathrm{Zn}, \mathrm{Cu}, \mathrm{Pb}, \mathrm{Cd}, \mathrm{As}$ and $\mathrm{Hg}$ ) in the Mediterranean mussel (Mytilus galloprovincialis) and evaluation of mussel quality and possible human health risk from cultivated and wild sites of the southeastern Adriatic Sea, Montenegro. J. Serb. Chem. Soc. 76, 1725-1737.

Steffen, W., Sanderson, A., Tyson, P.D., Jäger, J., Matson, P.A., Moore III, B., Oldfield, F., Turner, I.I.B.L., Wasson, R.J., 2004. Global Change and the Earth System: A Planet under Pressure. Springer-Verlag, Berlin-Heidelberg New York p. 336.

Szefer, P., Frelek, K., Szefer, K., Lee, C.h.B., Kim, B.S., Warzocha, J., Zdrojewska, I., Ciesielski, T., 2002. Distribution and relationships of trace metals in soft tissue, byssus and shells of Mytilus edulis trossulus from the southern Baltic. Environ. Pollut. 120, 423-444.

USEPA (United States Environmental Protection Agency), 2011. Risk-Based Concentration Table. U.S. EPA, Region 3, Philadelphia, PA, USA. 〈http://www.epa.gov/ reg3hwmd/risk/human/index.htm>.

USFDA (United States Food and Drug Administration), 1993. Guidance Document for Arsenic in Shellfish. Department of Health and Human Services, United States Food and Drug Administration.

Wang, H., Xu, Q., Yang, H.S., 2007. Heavy metal contents and quality evaluation of scallop in northern China seas (In Chinese). Mar. Sci. 31, 11-18.

Wang, Y.W., Liang, L.N., Shi, J.B., Jiang, G.B., 2005. Study on the contamination of heavy metals and their correlations in mollusks collected from coastal sites along the Chinese Bohai Sea. Environ. Int. 31, 1103-1113.

Whyte, A.L.H., Raumati Hook, G., Greening, G.E., Gibbs-Smith, E., Gardner, J.P.A. 2009. Human dietary exposure to heavy metals via the consumption of greenshell mussels (Perna canaliculus Gmelin 1791) from the Bay of Islands, northern New Zealand. Sci. Total Environ. 407 (14), 4348-4355.

WHO, 1982. Toxicological Evaluation of Certain Food Additives and Contaminants (WHO Food Additives Series No. 17). World Health Organization, Geneva, Switzerland, pp. 28-35.

Xu, S.S., Song, J.M., Yuan, H.M., Li, X.G., Li, N., Duan, L.Q., 2010. Effects of the combined pollution of $\mathrm{Cd}, \mathrm{Hg}, \mathrm{Pb}$ and petroleum hydrocarbons on common fishery species in the Bohai Bay (In Chinese). Asian J. Ecotoxicol. 5, 793-802.

Zhang, Y., Song, J.M., Yuan, H.M., Xu, Y.Y., He, Z.P., 2010. Concentrations of cadmium and zinc in seawater of Bohai Bay and their effects on biomarker responses in the bivalve Chlamys farreri. Arch. Environ. Contam. Toxicol. 59, $120-128$. 